\title{
Autologous Adrenal Medullary, Fetal Mesencephalic, and Fetal Adrenal Brain Transplantation in Parkinson's Disease: A Long-Term Postoperative Follow-Up
}

\author{
Ignacio Madrazo ${ }^{1}$, Rebecca Franco-Bourland ${ }^{2}$, Maricarmen Aguilera ${ }^{1}$, Feggy Ostrosky-Solis ${ }^{3}$, Mario \\ Madrazo $^{1}$, Carlos Cuevas ${ }^{1}$, Hugo Catrejon ${ }^{1}$, Gabriel Guizar-Zahagun ${ }^{1}$ and Eduardo Magallon
}

\author{
${ }^{1}$ Department of Clinical Research in Neurology and Neurosurgery, Hospital de Especialidades, Centro \\ Medico Siglo XXI, Instituto Mexicano del Seguro Social; ${ }^{2}$ Department of Biochemistry, Instituto Nacional \\ de la Nutricion "Salvador Zubiran", ${ }^{3}$ Department of Psychophysiology, Facultad de Psicologia, Universidad \\ Nacional Autonoma de Mexico, Mexico City, Mexico.
}

\begin{abstract}
We report on the clinical status of 5 patients with Parkinson's disease (PD) 3 years after autologous adrenal medullary (AM)-to-caudate nucleus (CN) implantation, and of 2 PD patients, 2 years after fetal ventral mesencephalon (VM)- and fetal adrenal (A)-to-CN homotransplantation. Current clinical evaluation of 4 of the AM grafted patients revealed sustained bilateral amelioration of their PD signs, most notably of rigidity, postural imbalance and gait disturbances, resulting in a substantial improvement in their quality of life. The disease-related dystonia of one of them disappeared only 2 years after surgery. The levodopa requirements of 2 of these patients and the anticholinergic therapy of another have been reduced. In agreement with the satisfactory clinical evaluation of these 4 patients, their neuropsychological and electrophysiological improvements, initially registered 3 months after surgery, have been maintained
\end{abstract}

Reprint address:

Ignacio Madrazo, MD, DSc

Calzada de Tlalpan 4430

14300 Mexico DF, Mexico. for 3 years. After 1 year of significant recovery, the 5 th patient of this group has almost returned to her preoperative state.

The 2 homotransplanted patients also showed sustained bilateral improvement of their PD signs. Two years after surgery, the most improved signs of the fetal VM case were rigidity, bradykinesia, postural imbalance, gait disturbances and facial expression. The fetal $A$ case has only shown amelioration of rigidity and bradykinesia. Neither of them has shown significant neuropsychological changes. Their current levodopa requirements are less than before surgery.

The improvements shown here by $P D$ patients after brain tissue grafts go beyond those obtained using any other therapeutic approach, when levodopa fails. Although more studies and the development of these procedures are obviously required, these initial human trials appear to be resisting the test of time.

Key words: Human brain transplantation; fetal grafts; adrenal grafts; Parkinson's disease. 


\section{INTRODUCTION}

PATIENTS AND METHODS
Parkinson's disease (PD) is a chronic, progressive neurological disorder of unknown cause, mainly due to the degeneration of nigrostriatal dopaminergic neurons, that leads to severe disturbances of motor function. To date, there have been no reports of spontaneous remission of the disease. For a few years, the deficient neurotransmission can be corrected, and the symptoms and signs ameliorated with exogenous levodopa /1/. In time, however, with the progression of the disease, patients also become tolerant to the drug $/ 18 /$, and/or develop adverse side effects, trapping the patient in an untreatable and most disabling situation.

With the aim of providing a therapeutic alternative for these patients, we turned to the use of dopamine (DA)-rich brain grafts [adult adrenal medullary (AM), fetal ventral mesencephalon (VM) and fetal adrenal (A) tissues] which, implanted in the striatum of animal models of the disease, improved their motor disturbances /2/. In 1987 we reported /8/ on the short term beneficial effects of autologous DA-rich AM brain transplants to the caudate nucleus $(\mathrm{CN})$ of two patients suffering from PD. In 1988, we presented the initial beneficial effects of fetal VM and fetal A implants to the first 2 homotransplanted parkinsonians $/ 17 /$. Because of the sustained amelioration of their PD signs, we gradually extended our brain transplantation program, and have now autotransplanted a total of 67 patients (60 using our cavitation procedure $/ 8,10,16 /, 5$ with a multiple site implantation technique $/ 7 /$. and 2 with $A M-$ intercostal peripheral nerve co-grafts), and a total of 7 parkinsonians have received human fetal tissue.

The therapeutic value of these neurosurgical procedures in treating PD rests on the fact that they should produce long lasting beneficial effects. It has thus been our concern to monitor carefully our patients over time $/ 9,11,13-16 /$, in order to establish the effectiveness of these surgical procedures. Here we present the followup of the 5 autotransplanted parkinsonians who have reached 3 years after surgery, and the 2 year follow-up of the first 2 patients with fetal homotransplants.

\section{Clinical data}

The 5 autotransplanted patients included 3 males (JMC, farmer, with a grade school education; FPT, subway employee, with a grade school education; NAG, civil engineer), and 2 females (MSP, housewife, with a grade school education; MAO, assistant accountant), all of them unable to work. Their ages at surgery were 35, 47 and 33, and 51 and 59 years, respectively. The durations of their illness were 5, 8 and 10, and 5 and 5 years, respectively. Three of the patients were under chronic levodopa therapy. FPT was receiving $1,000 \mathrm{mg} /$ day, NAG 500 $\mathrm{mg} /$ day and MAO $1,750 \mathrm{mg} /$ day. The other 2 could not tolerate levodopa. One of them (JMC) did not tolerate any medication, and the other (MSP) was being treated with an anticholinergic drug (biperiden) at a dose of $8 \mathrm{mg} /$ day. Patients on levodopa therapy presented "on-off" phenomena, and dyskinesia during their "on" periods. MSP showed disease-related dystonia.

The patient who underwent fetal VM brain homotransplantation was a 50-year-old salesman, with a grade school education (MTM), who had had PD for 9 years, was receiving 1,000 $\mathrm{mg} /$ day of levodopa, and presented drug-induced dystonia and dyskinesia. The patient who received the fetal A graft was a 35-year-old housewife, with secretarial training (LBC), with a 5 year evolution of PD, and who was on 750 $\mathrm{mg} /$ day of levodopa.

The pre- and postoperative severity of the disease was measured on the Unified Parkinsonism Rating Scale (UPRS) /21/, the Hoehn and Yahr $15 /$, the Schwab and England /20/ and our performance scales /8,16/. Patients were also subjected to pre- and postoperative neuropsychological /19/ and electrophysiological evaluations.

Brain and adrenal gland computed tomography, brain magnetic resonance imagings (MRI), and brain scintigraphy /4/ were obtained at various times throughout the study. Fig. 1 shows the brain MRI of MTM (the first VM-CN fetal homotransplanted patient) 30 months postsurgery. Further details are given in the Figure legend.

Biochemical analyses of lumbar and 
ventricular CSF /3/ were discontinued 1 year postsurgery for ethical considerations.

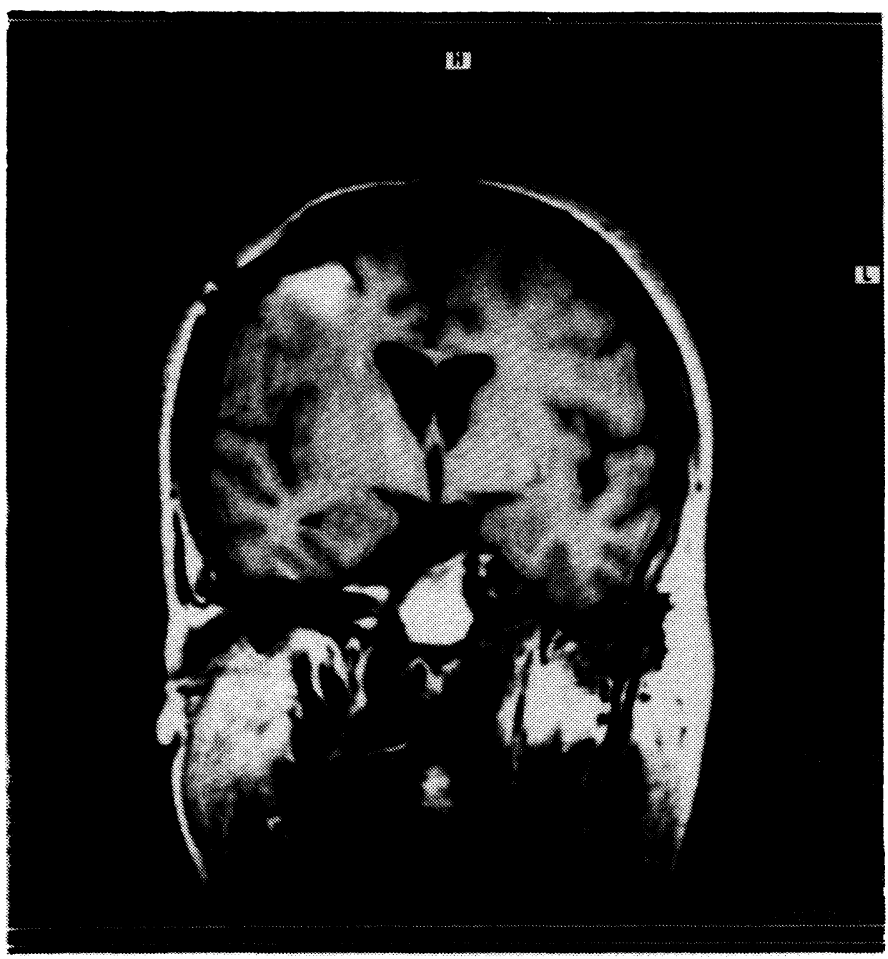

Fig. 1: Brain MRI of MTM (first VM-to-CN fetal homotransplanted patient) 30 months postsurgery. Ventricular asymmetry is due to hypotrophy of the right CN. Paraventricular images reveal heterogeneous hyperintensities of the right $\mathrm{CN}$, possibly due to gliosis and/or the graft. Slight corticosubcortical atrophy is evident. Postsurgical right frontal lobe gliosis and craniotomy are visible. (Courtesy of the Department of Magnetic Resonance Imaging, Hospital Angeles del Pedregal, Mexico City).

\section{Surgery}

The brain transplantation method we designed to implant both freshly excised autologous AM fragments or human fetal tissue has been described in detail elsewhere $/ 10,12,16 /$. Human fetal VM was dissected with a hands-free technique in order to ensure the intactness of the tissue $/ 6 /$.
RESULTS

\section{AM autotransplants}

Table 1 shows the UPRS scores of the 5 autotransplanted parkinsonians in their preoperative and postoperative conditions 1 and 3 years after surgery. One (JMC) had severe PD and 4 were moderate to severe cases. Three years after surgery, 4 of them have maintained the level of recovery seen at one year postsurgery, that is, have maintained a change on the UPRS of more than 30 points. Improvements were observed in the length and quality of the "on" periods, as well as in the reduced frequency of motor fluctuations. In fact, the 2 patients now on a reduced or suppressed levodopa therapy have stopped fluctuating. Patients' recovery has been bilateral and symmetric. The most improved signs have been rigidity, postural imbalance and gait disturbances.

Three of the AM transplanted patients improved progressively until they reached a steady state approximately 6 to 10 months posttransplant, which has remained stable now for 3 years. During this time, patients showed oscillations in the intensity of their PD signs, usually related to their depressive state, stress, and/or levodopa dosage adjustments. However, none of these patients has shown a sustained regression of symptoms. In one patient (MSP), the diseaserelated dystonia, which was manifest at her one year evaluation, notably disappeared 2 years after surgery. MAO, who showed a moderate response to surgery one year after brain grafting, has become worse over time, although in "on", she has not deteriorated to her preoperative state. AM patients' evaluations on the Hoehn and Yahr, Schwab and England, and on our performance scales were congruent with these results. Preoperatively all patients were occupationally impaired. After surgery, 3 of them (JMC, NAG, MSP) have been able to return to their original occupations, and one of them (FPT) is now a merchant. MAO has remained impaired.

The current postoperative levodopa therapy of the autotransplanted patients is indicated in Table 2. Of the 3 autotransplanted patients who were taking levodopa before surgery, the current postoperative dose of one of them (NAG) has been significantly reduced, and that of another 


\section{TABLE 1}

Pre- and postoperative UPRS scores of autoadrenal medullary brain transplanted parkinsonians

\begin{tabular}{|c|c|c|c|c|c|c|c|}
\hline \multirow{3}{*}{ Patient } & \multicolumn{3}{|c|}{$\mathrm{ON}^{\mathrm{a}}$} & \multicolumn{3}{|c|}{$\mathrm{OFF}^{\mathrm{b}}$} & \multirow{3}{*}{$\begin{array}{l}\text { CURRENT } \\
\text { CLINICAL } \\
\text { STATUS }\end{array}$} \\
\hline & \multirow[t]{2}{*}{ Preoperative } & \multicolumn{2}{|c|}{ Postoperative } & \multirow[t]{2}{*}{ Preoperative } & \multicolumn{2}{|c|}{ Postoperative } & \\
\hline & & 1 year & 3 years & & 1 year & 3 years & \\
\hline JMC & -- & -- & --- & 121 & 82 & 80 & good \\
\hline FPT & 56 & -- & --- & 75 & 40 & 43 & good \\
\hline NAG & 58 & 8 & 6 & 86 & 15 & 18 & good \\
\hline MSP & --- & $-\ldots$ & --- & 80 & 31 & 26 & good \\
\hline MAO & 80 & 60 & 72 & 85 & 55 & 86 & poor \\
\hline
\end{tabular}

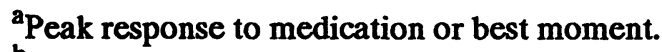

borst spontaneous or induced moment.

(FPT) suppressed. For MAO, levodopa has increased in the last 2 years, due to progressive deterioration. One (JMC) of the 2 patients intolerant to this medication before surgery, and who did well without levodopa for 15 months postsurgery, currently requires and is responding well to small doses of the drug ( $375 \mathrm{mg} /$ day), while the other (MSP) is doing well on a lower dose of anticholinergic medication (biperiden, 3 $\mathrm{mg} /$ day), without the use of levodopa.

Pre- and postoperative neuropsychological and electrophysiological (P300) profiles of MSP are shown in Figs. 2 and 3, respectively. In her preoperative neuropsychological evaluation, MSP showed frontal lobe-type deficits, with alterations in behavioral programming, leading to difficulties in the organization of motor sequences and alternating programs. Visuospatial and visuoperceptual tasks were also affected, showing loss of figure-ground perspective and fragmentation. Immediate memory was diminished, and there were marked difficulties in delayed memory. There was formal perseveration of reading and writing, although motor problems affected the quality of the written product. She could perform basic arithmetical operations, but had difficulty counting backwards from 100 in

\section{TABLE 2}

Pre- and postoperative levodopa therapy of autoadrenal medullary brain transplanted parkinsonians

\begin{tabular}{lccc}
\hline & \multicolumn{2}{c}{ mg/day } \\
& Patient & \multicolumn{2}{c}{ Postoperative } \\
& Preoperative & 1 year & 3 years \\
\cline { 2 - 4 } JMC & 0 & 0 & 375 \\
FPT & 1000 & 0 & 0 \\
NAG & 500 & 250 & 250 \\
MSP & 0 & 0 & 0 \\
MAO & 1750 & 375 & 1000 \\
\hline
\end{tabular}

a Has been on an anticholinergic therapy (biperiden): preoperative dose: $8 \mathrm{mg} /$ day; postoperative dose of years, $3 \mathrm{mg} /$ day. 


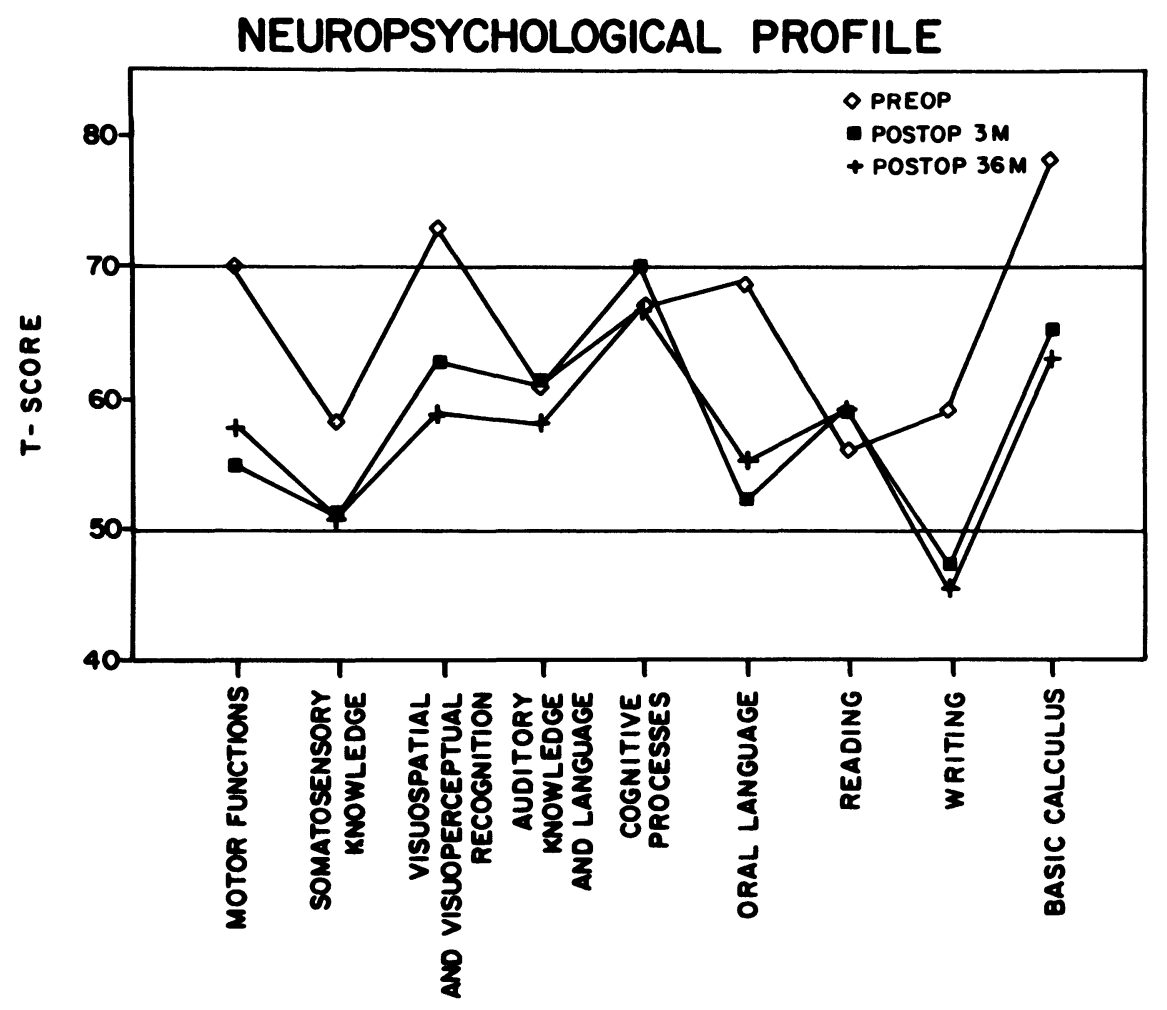

Fig. 2: Neuropsychological profiles of MSP before and 3 and 36 months after AM-to-CN autotransplantation. Higher scores reflect a greater number of errors than average and lower scores the opposite. M: months.

7's. MSP's postoperative evaluation, carried out 3 months after surgery, revealed an amelioration of frontal-lobe symptoms, and of visuospatial deficits, as well as the improved quality of her writing due to an important reduction in tremor. These improvements remained unchanged after 36 months. Of the $5 \mathrm{AM}$ autotransplanted patients, 3 of them showed specific cognitive deficits in their preoperative neuropsychological evaluations. The postoperative evaluations of 2 of these patients revealed an amelioration of their frontal-lobe type symptoms and visuospatial deficits that has been maintained for 36 months. In the case of MAO, only minor neuropsychological improvements were observed one year after surgery, and at her 36-month evaluation her neuropsychological profile proved to be very similar to her preoperative state. FPT, who preoperatively showed a depressive symptomatology, has suffered recurrent depressive episodes after surgery that have been controlled pharmacologically.
Electrophysiological data, obtained from long latency auditory evoked potentials, have revealed a significant change in the amplitude of the P300 component and a shortening of the latency of the N100 component that have been sustained in 3 patients for 36 months postsurgery.

\section{Fetal homotransplants}

The postoperative UPRS courses in "on" and "off" of the 2 homotransplanted parkinsonians are shown in Fig. 4, together with the corresponding levodopa requirements. MTM with the VM homograft, 5 months after surgery, had significant amelioration of rigidity, bradykinesia, postural imbalance, gait disturbances and facial expression, but tremor was a remaining sign. At his 2 year evaluation, tremor has further decreased and, in general, his current clinical status is very good. Today, he leads a normal life, and has gone back to work. 


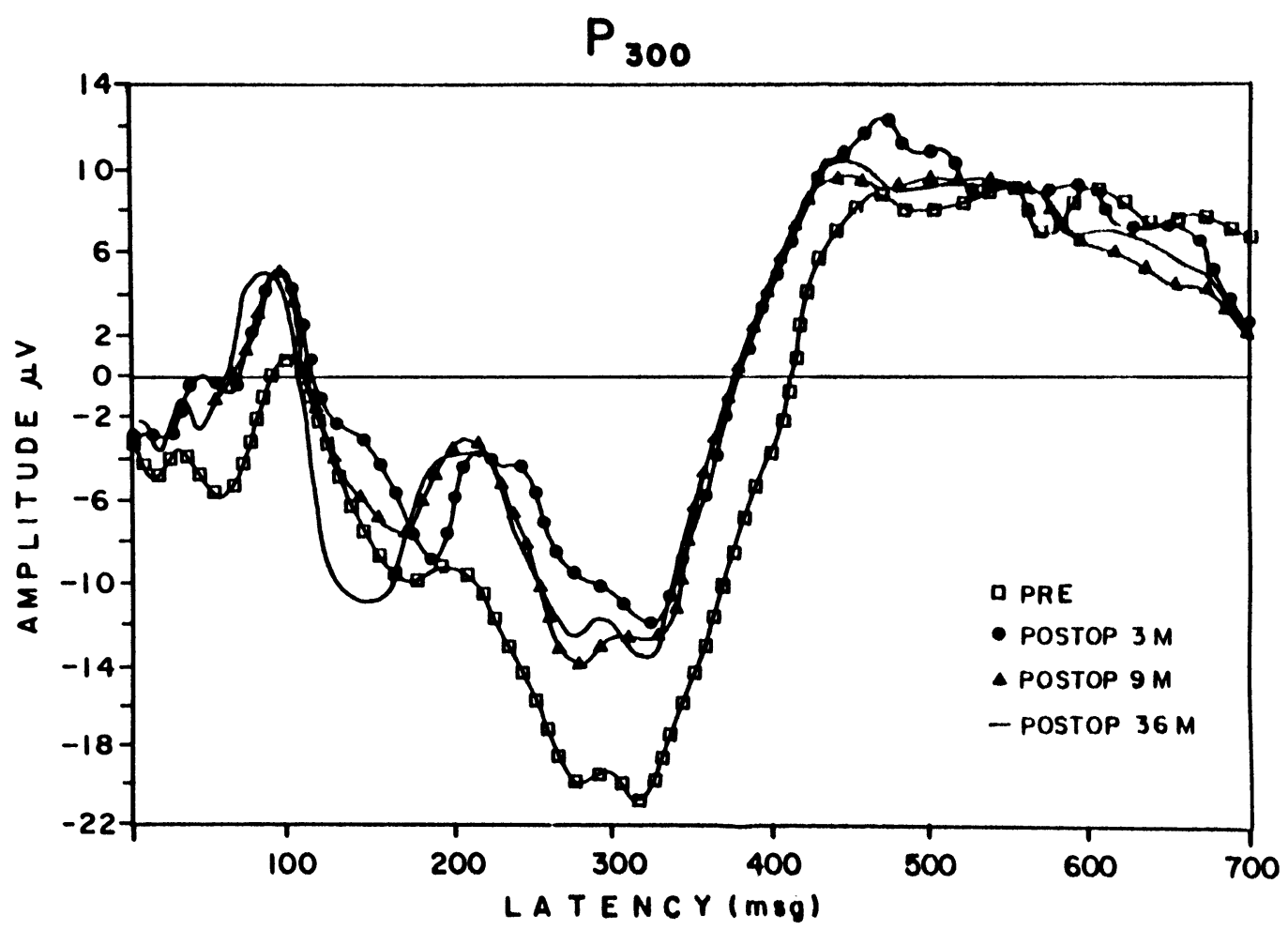

Fig. 3: Electrophysiological profiles of MSP before and 3, 9 and 36 months after AM-to-CN autotransplantation. M: months.

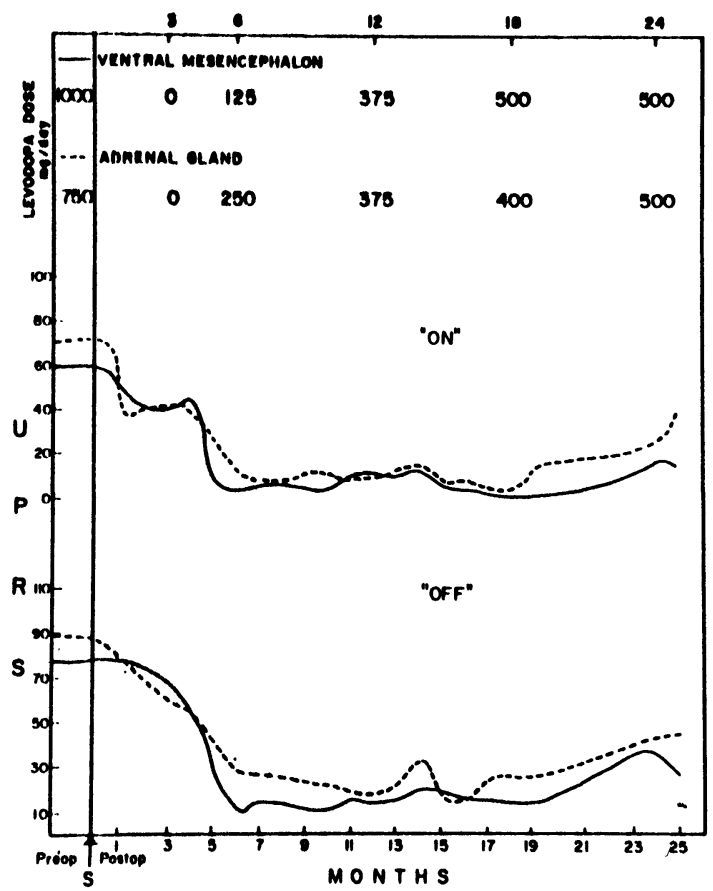

Fig. 4: Two year postoperative UPRS courses in "on" and "off" of the first 2 parkinsonians homotransplanted with fetal VM or fetal A.
LBC, the fetal A transplanted patient, has. shown significant amelioration of only rigidity and bradykinesia, without important changes in the other signs. Though her current clinical status is moderate, she is now able to perform household tasks. Her current levodopa requirements are much closer to her preoperative level of medication, compared with MTM, whose current levodopa intake is only half that of his preoperative dose. Both patients have been maintained on $1 \mathrm{mg} / \mathrm{kg}$ PO cyclosporin $\mathrm{A}$, with serum levels ranging between 150-200 $\mathrm{ng} / \mathrm{ml}$ (Sandoz, RIA).

\section{CONCLUDING REMARKS}

From these data, we may conclude that 3 years after autoadrenal transplantation, and 2 years after fetal VM or A homotransplantation, to varying degrees, and regardless of the 
mechanisms of action involved, these brain transplantations are effective procedures to ameliorate PD signs to an extent not achieved by any other means. Currently, efforts are being devoted to establish the best candidates for surgery and the best donor tissue, as well as the best implantation technique.

We strongly believe that, with the current state of knowledge regarding brain transplantations, we cannot disregard the usefulness of any type of graft for the treatment of neurological diseases. Though at this time fetal tissue seems to be the most useful graft, autotransplants, which do not require immunosuppression, as well as genetically modified cells, will in time assume their place as implantation alternatives for each individual patient.

\section{ACKNOWLEDGEMENTS}

This work was partially supported by the FIIRESIN (Interinstitutional Research Foundation for Studies on the Regeneration of the Nervous System, Mexico).

\section{REFERENCES}

1. Bernheimer $\mathrm{H}$, Birkmayer $\mathrm{W}$, Hornykiewicz $\mathrm{O}$, Jellinger $\mathrm{K}$, Seitelberger $\mathrm{F}$. Brain dopamine and syndromes of Parkinson and Huntington. J Neurol Sci 1975; 30: 415-455.

2. Bjorklund A, Stenevi U, eds., Neural Grafting in the Mammalian CNS. Fernström Foundation Series, Vol. 5. Amsterdam: Elsevier, 1985.

3. Franco-Bourland RE, Madrazo I. Trasplantes al cerebro. Aspectos bioquimicos. Bol Syntex Inform Med 1988; 14: 5-6.

4. Graef A, Franco-Bourland RE, Marquez A, Madrazo I, Drucker-Colin R, Torres C, Alvarez F, Manzano E. (Spon: V Aleman), ${ }^{131}$ I-meta-iodobenzylguanidine scintigrams of adrenomedullary autotransplants to the caudate nucleus of parkinsonians. Soc Neurosci Abstr 1988; 14: 4.

5. Hoehn MM, Yahr MD. Parkinsonism: Onset, progression, and mortality. Neurology 1967; 17: 427 442.

6. Madrazo I, Aguilera MC, Franco-Bourland RE, Guizar G. Human fetal ventral mesencephalon for brain transplantation to parkinsonians: A hands-free dissecting technique. Eric K Fernström Symposium.
Intracerebral transplantation in movement disorders. Experimental basis and clinical experiences. June 20 22, 1990, Lund, Sweden.

7. Madrazo I, Cuevas C, Franco-Bourland RE, Aguilera MC, Castrejon H, Ostrosky-Solis F. Multiple-site implantation of autologous adrenomedullary tissue to caudate nucleus for the treatment of Parkinson's disease. Eric K Fernström Symposium, Intracerebral transplantation in movement disorders. Experimental basis and clinical experiences. June 20 - 22, 1990, Lund, Sweden.

8. Madrazo I, Drucker-Colin R, Diaz V, Martinez-Mata J, Torres C, Becerril JJ. Open microsurgical autograft of adrenal medulla to the right caudate nucleus in two patients with intractable Parkinson's disease. $\mathrm{N}$ Engl J Med 1987; 316: 831-834.

9. Madrazo I, Drucker-Colin R, Leon V, Torres C. Adrenal medulla transplanted to caudate nucleus for treatment of Parkinson's disease: Report of 10 cases. Surg Forum 1987; 38: 510-512.

10. Madrazo I, Drucker-Colin R, Madrazo M, Zarate A Leon $\mathrm{V}$, Torres $\mathrm{C}$, Reyes $\mathrm{P}$. Tecnica quirurgica del injerto autologo de medula suprarrenal al nucleo caudado para tratamiento de la enfermedad de Parkinson. Gac Med Mex 1988; 124: 365-369.

11. Madrazo I, Franco-Bourland R, Aguilera MC, Ostrosky-Solis F. Hispanic registry of graft procedures for Parkinson's disease. Lancet 1989; ii: 751-752.

12. Madrazo I, Franco-Bourland R, Aguilera M, Reyes $P$, Guizar-Sahagun G. Balloon needle for the atraumatic transcortical ventricular approach. Technical note. Surg Neurol 1990; 33: 226-227.

13. Madrazo I, Franco-Bourland RE, Ostrosky F, Aguilera MC, Candelas JA. Human brain transplantation of adrenomedullary and fetal brain tissue for functional restoration in the diseased brain (clinical experience in Parkinson's disease). In: Hatase $\mathrm{O}$, Wang JH, eds, Bioinformatics. Proceedings of the International Symposium on Information, Transduction and Processing in Biological Systems From Cell to Whole Body. Amsterdam: Elsevier, 1989; 289-296.

14. Madrazo I, Franco-Bourland R, Ostrosky-Solis F, Aguilera M, Cuevas C, Alvarez F, Magallon E, Zamorano C, Morelos A. Neural transplantation (auto-adrenal, fetal nigral, and fetal adrenal) in Parkinson's disease - the Mexican experience. In: Dunnet S, Richards SJ, eds, Neural Transplantation: From Molecular Basis to Clinical Application. Progress in Brain Research, Vol. 82. Amsterdam: Elsevier, 1990; 593-602.

15. Madrazo I, Drucker-Colin R, Torres C, OstroskySolis F, Franco-Bourland RE, Aguilera MC, Garcia L, Alvarez F, Candelas J, Quintanar L. Long-term changes in Parkinson's disease patients with adrenal medullary auto-grafts to the caudate nucleus. In: 
Bunney WE Jr, Hippius H, Laakmann G, Schmauss $M$, eds, Neuropsychopharmacology. Proceedings of the XVIth C.I.N.P. Congress. Berlin: Springer Verlag, $1990 ; 118-132$.

16. Madrazo I, Garcia L, Torres C, Aguilera MC, Reyes P, Candelas JA, Ostrosky F, Drucker-Colin R, Meneses S, Franco-Bourland R. Initial neurotransplants in humans. In: Koller WC, Paulson G, eds, Therapy of Parkinson's Disease. New York: Marcel Dekker, 1990; 473-499.

17. Madrazo I, Leon V, Torres C, Aguilera MC, Varela G, Alvarez F, Fraga A, Drucker-Colin R, Ostrosky F, Skurovich M, Franco R. Transplantation of fetal substantia nigra and adrenal medulla to the caudate nucleus in two patients with Parkinson's disease. $\mathrm{N}$ Engl J Med 1988; 318: 51.

18. Marsden CD, Parkes JD, Quinn N. Fluctuations of disability in Parkinson's disease: Clinical aspects. In: Marsden CD, Fahn S, eds, Movement Disorders. London: Butterworth Scientific, 1981; 96-122.

19. Ostrosky-Solis F, Quintanar L, Madrazo I, DruckerColin R, Franco-Bourland R, Leon-Meza V. Neuropsychological effects of brain autograft of adrenal medullary tissue for the treatment of Parkinson's disease. Neurology 1988; 38: 1442-1450.

20. Schwab RS, England AC Jr. Projection technique for evaluating surgery in Parkinson's disease. In: Gillingham FJ, Donaldson IML, eds, Third Symposium on Parkinson's Disease. Edinburgh: Livingstone, 1968; 152-157.

21. Unified Rating Scale for Parkinsonism, Version 2.0, December 1985. In: Koller WC, ed, Handbook for Parkinson's - Disease. New York: Marcel Dekker, $1987 ; 482-488$. 

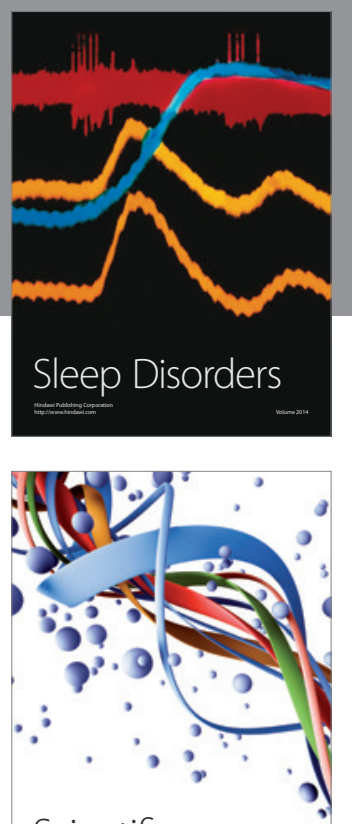

Scientifica
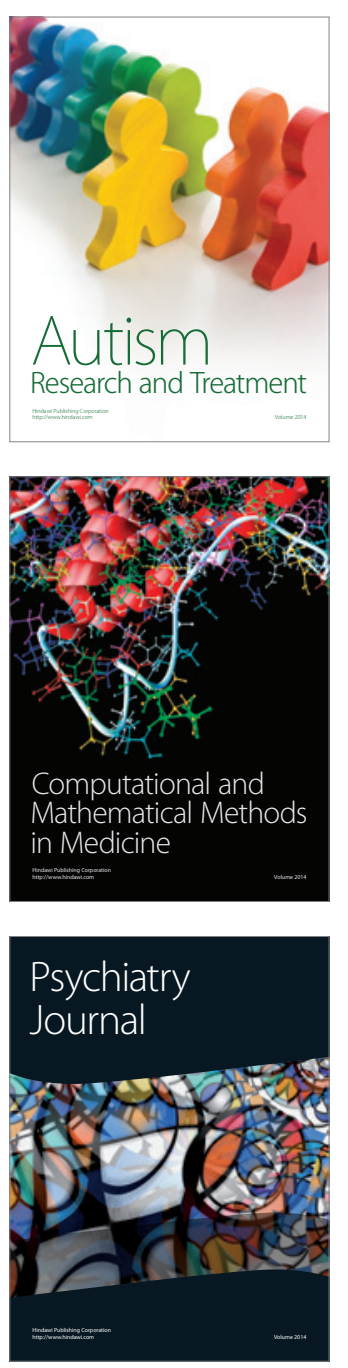
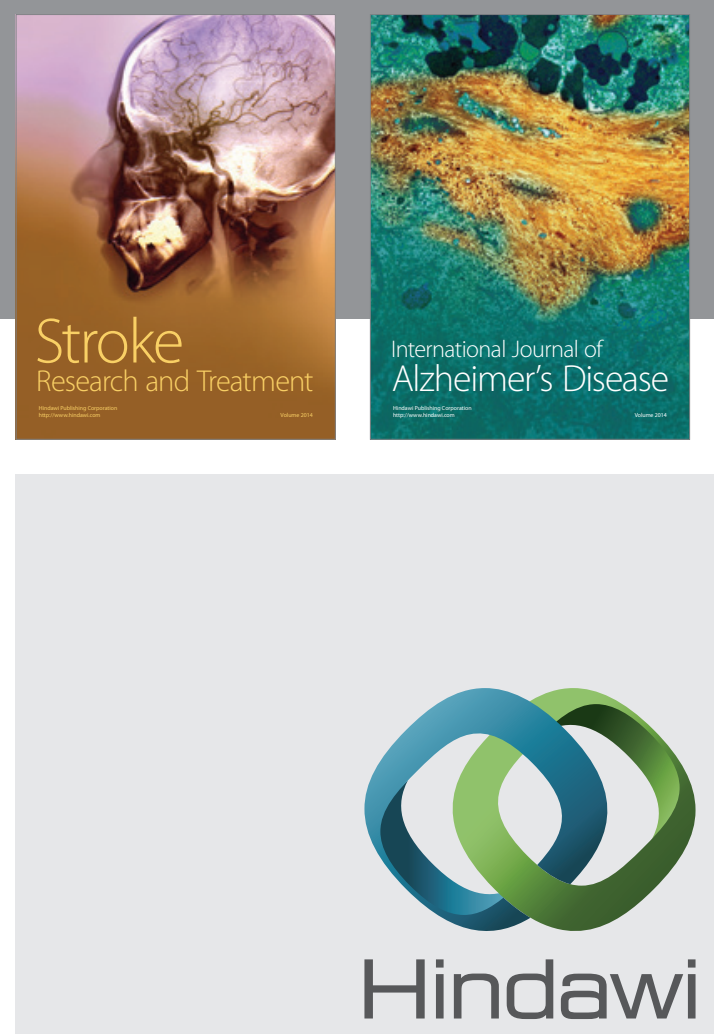

Submit your manuscripts at

http://www.hindawi.com
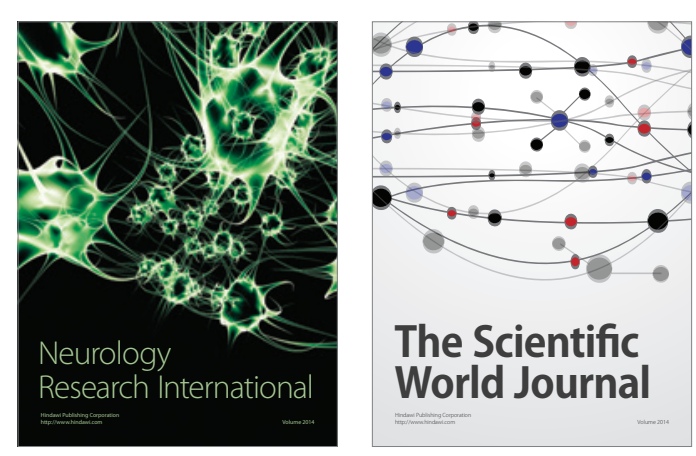

The Scientific World Journal

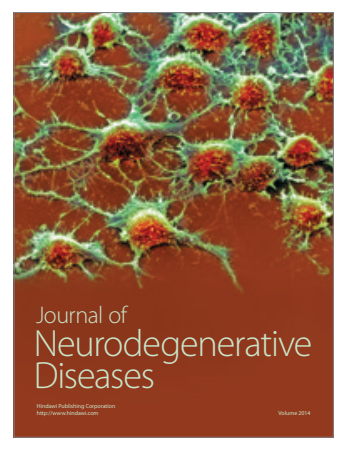

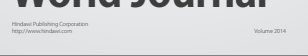

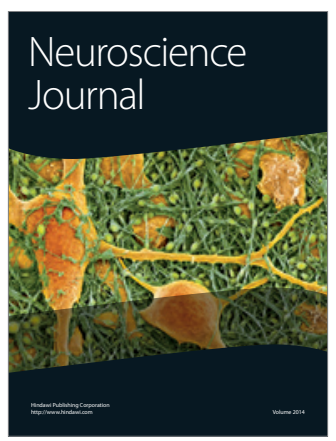

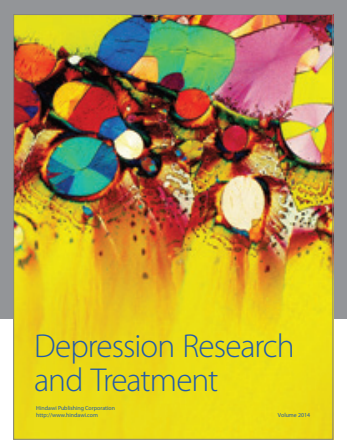
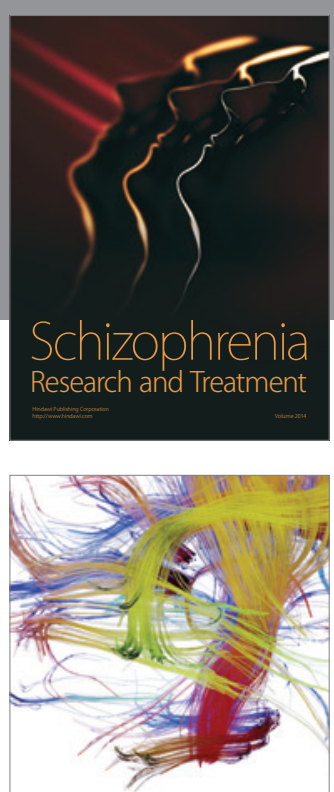

Brain Science

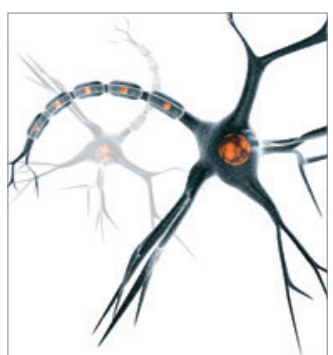

Neural Plasticity
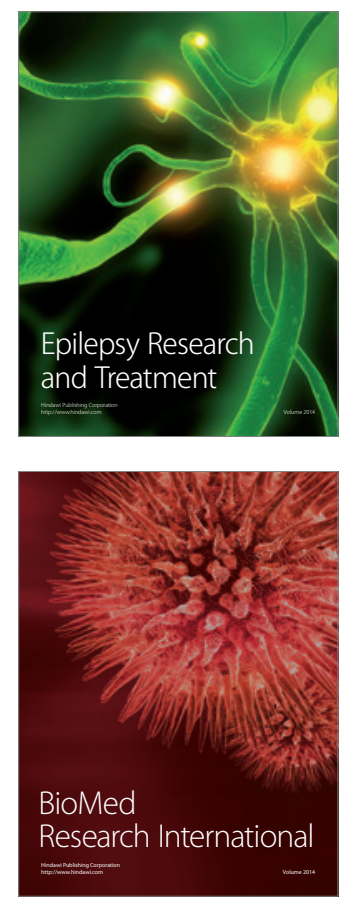

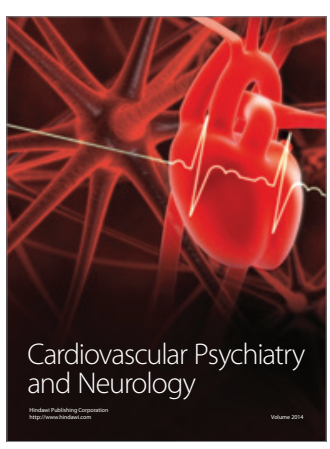

Parkinson's

Disease
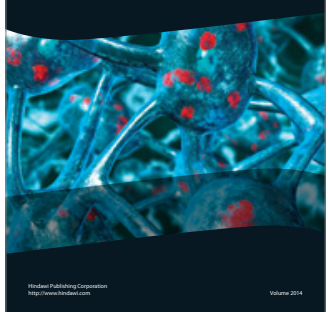